\title{
PENERAPAN METODE INQUIRY DIPADU TRIK TAKTIK WAKTU BERTANYA UNTUK MENINGKATKAN KEMAMPUAN BERPIKIR KRITIS DAN HASIL BELAJAR KONSEP SEL PADA SISWA KELAS VII SMP KARTIKA AMBON
}

\author{
Jeli Samadara ${ }^{1}$, S.I.A. Salmanu ${ }^{2}$ \\ ${ }^{1}$ Alumni Program Studi Pendidikan Biologi \\ ${ }^{2}$ Dosen Program Studi Pendidikan Biologi \\ E-mail: salmanusriyanti@yahoo.com
}

\begin{abstract}
Background: Inquiry method is a method that can stimulate students to find their own answers to problems that students face in class. Through this learning method students can mobilize all abilities and knowledge they have, in finding answers to existing problems, so students can think critically in the learning process.

Method: This study was conducted in class VII1 in the Kartika Middle School in Ambon. This study uses descriptive analysis that is used to determine critical thinking skills and cognitive, affective, and psychomotor learning outcomes of students.

Results: The study showed that mastery of cell concepts in students before the application of the Inquiry method combined with tactics tricks when asking was very low. This can be seen from the percentage of the average score obtained by students in the initial test which is $31 \%$ which includes failed qualifications because it does not reach the KKM which is set at 75 . After the application of the Inquiry method combined with tactics when asking questions, the results of the formative tests obtained by students increase with the average percentage of achievement is $71.51 \%$. To assess students 'critical thinking skills through worksheets and observation sheets, the results show that there is an increase in students' critical thinking skills.

Conclusion: The application of the Inquiry method combined with tactics when asking questions can improve students' critical thinking skills and achievement of learning outcomes in cell concept biology.
\end{abstract}

Keywords: Inquiry method, strategy tactics when asking questions, critical thinking, learning outcomes.

\begin{abstract}
Abstrak
Latar Belakang: Metode Inquiry merupakan metode yang dapat merangsang siswa untuk dapat menemukan sendiri jawaban dari permasalahan yang siswa hadapi di kelas. Melalui metode pembelajaran ini siswa dapat mengerahkan segala kemampuan dan pengetahuan yang dimiliki, dalam mencari jawaban dari permasalahan yang ada, sehingga siswa dapat berpikir secara kritis dalam proses pembelajaran.

Metode: Penelitian ini dilaksanakan pada kelas VII ${ }^{1}$ di SMP Kartika Ambon. Penelitian ini menggunakan analisis deskriptif yang digunakan untuk mengetahui kemampuan berpikir kritis dan hasil belajar kognitif, afektif, dan psikomotor siswa.

Hasil: Penelitian menunjukkan bahwa penguasaan konsep sel pada siswa sebelum penerapan metode Inquiry dipadu trik taktik waktu bertanya tergolong sangat rendah. Hal ini terlihat dari prosentase nilai rata-rata yang diperoleh siswa pada tes awal yaitu $31 \%$ yang termasuk kualifikasi gagal karena tidak mencapai KKM yang ditetapakan yaitu 75 . Setelah penerapan metode Inquiry dipadu trik taktik waktu bertanya, hasil tes formatif yang diperoleh siswa menjadi meningkat dengan persentase rata-rata pencapaian yaitu $71,51 \%$. Untuk penilaian kemampuan berpikir kritis siswa dilakukan melalui hasil kerja LKS dan lembar observasi dan diperoleh hasil bahwa terjadi peningkatan kemampuan berpikir kritis pada siswa.

Kesimpulan: Penerapan metode Inquiry dipadu trik taktik waktu bertanya dapat meningkatkan kemampuan berpikir kritis siswa dan pencapaian hasil belajar biologi konsep sel.
\end{abstract}

Kata Kunci: Metode Inquiry, strategi trik taktik waktu bertanya, berpikir kritis, hasil belajar. 


\section{PENDAHULUAN}

Saptono (2003), menyatakan bahwa pembelajaran biologi di sekolah dapat dikatakan unik karena baik subjek maupun objek pembelajarannya memiliki karakter yang khas. Objek pembelajaran biologi selain berhubungan dengan alam nyata, juga berkaitan dengan proses-proses kehidupan yang masih abstrak bagi siswa. Agar siswa dapat memahaminya, maka metode dan strategi yang digunakan dalam proses pembelajaran harus disesuaikan dengan karakteristik subjek dan objek belajarnya. Amien (1987), mengungkapkan bahwa metode Inquiry merupakan metode yang dapat merangsang siswa untuk dapat menemukan sendiri jawaban dari permasalahan yang siswa hadapi di kelas. Melalui metode pembelajaran ini siswa dapat mengerahkan segala kemampuan dan pengetahuan yang dimiliki, dalam mencari jawaban dari permasalahan yang ada, sehingga siswa dapat berpikir secara kritis dalam proses pembelajaran. Siswa akan terpancing dengan pertanyaanpertanyaan maupun pernyataan-pertanyaan yang ada, sehingga siswa berpikir kritis untuk mencari jawaban dari pertanyaan tersebut. Metode pembelajaran ini bukan sekedar menghafal dan menumpuk ilmu pengetahuan, tetapi juga bagaimana pengetahuan yang diperolehnya lebih bermakna untuk siswa melalui segala daya pikir siswa. Metode Inquiry tidak hanya dituntut agar menguasai materi pelajaran, tetapi bagaimana siswa dapat menggunakan potensi yang dimilikinya.

Sofa (2008), menyatakan bahwa Metode Inquiry merupakan metode pembelajaran yang banyak dianjurkan, oleh karena metode ini memiliki beberapa kelebihan diantaranya: 1) Merupakan metode pembelajaran yang menekankan kepada pengembangan aspek kognitif, afektif dan psikomotor secara seimbang, sehingga pembelajaran melalui metode ini lebih bermakna, 2) Dapat memberikan ruang kepada siswa untuk belajar sesuai dengan gaya belajar mereka; 3) Merupakan metode yang dianggap sesuai perkembangan psikologi belajar modern yang menganggap belajar adalah proses perubahan tingkah laku berkat adanya pengalaman dan 4) Keunggulan lain dari metode pembelajaran ini dapat melayani kebutuhan siswa yang memiliki kemampuan di atas rata-rata. Artinya siswa yang memiliki kemampuan belajar bagus tidak akan terhambat oleh siswa yang lemah dalam belajar.

Hasil penelitian yang mendukung penggunaan metode Inquiry adalah Nurlitasari (2015) tentang pengaruh penerapan metode Inquiry unuk meningkatkan kemampuan berpikir dan hasil belajar siswa kelas X-2 SMA LAB UM Malang menyimpulkan bahwa adanya peningkatan kemampuan berpikir dan prestasi hasil belajar siswa selama pemberian tindakan. Di samping itu pula ada satu strategi pembelajaran yang dipadukan dengan metode ini yaitu trik taktik waktu bertanya. Strategi trik taktik waktu bertanya sangat efektif untuk digunakan dalam proses pembelajaran sehingga membuat proses belajar siswa jadi menyenangkan. Menurut Roswita (2013), strategi trik taktik waktu bertanya diartikan sebagai suatu strategi yang dalam proses pembelajaran berusaha melatih siswa dalam kecakapan belajar yaitu mengajukan pertanyaan yang benar sekaligus mencari jawaban dari sumbersumber yang telah disediakan. Strategi trik taktik waktu bertanya mengajarkan siswa untuk berpikir kritis secara kooperatif dan sekaligus mandiri. Disebut kritis karena siswa dapat berpikir dari objek atau gambar yang telah disediakan, dimana setiap gambar dapat menimbulkan banyak pertanyaan.

Berdasarkan hasil wawancara dengan guru mata pelajaran biologi dan beberapa siswa SMP Kartika Ambon menyatakan bahwa dalam proses pembelajaran biologi, guru kurang kreatif dalam menerapkan metode dan model pembelajaran yang ada. $\mathrm{Hal}$ ini berefek kepada tingkat kemampuan berpikir dan hasil belajar siswa sehingga kurang maksimal atau tidak mencapai KKM yang telah ditetapkan yaitu 75 , khususnya pada mata pelajaran IPA biologi. Sehingga perlu diterapkan metode Inquiry dipadu trik taktik waktu bertanya yang diprediksi akan dapat menjawab tantangan kondisi pembelajaran yang terjadi di SMP Kartika Ambon. 


\section{MATERIAL DAN METODE}

Penelitian ini merupakan penelitian deskriptif yang bertujuan untuk menggambarkan penerapan metode pembelajaran Inquiry dipadu trik taktik waktu bertanya untuk meningkatkan kemampuan berpikir kritis dan hasil belajar siswa pada konsep sel. Penelitian ini dilaksanakan di SMP Kartika Ambon dari tanggal 25 Juli sampai dengan 25 Agustus 2018.

Populasi yang digunakan dalam penelitian ini yaitu seluruh siswa kelas VII SMP Kartika Ambon. Sampel yang digunakan dalam penelitian ini yaitu siswa kelas VII ${ }_{1}$ SMP Katika Ambon dengan jumlah siswa 20 orang. Variabel yang digunakan dalam penelitian ini adalah variabel bebas yaitu pembelajaran dengan menggunakan metode pembelajaran Inquiry dipadu trik taktik waktu bertanya dan variabel terikat yang meliputi kemampuan berpikir kritis dan hasil belajar siswa pada konsep sel.

Data dalam penelitian ini diperoleh melalui tes awal, tes akhir, dan lembar observasi untuk mengetahui kemampuan afektif, psikomotor, serta kemampuan berpikir kritis. Data kognitif diperoleh melalui LKS yang dikerjakan oleh siswa. Kemudian data diolah menggunakan analisis deskriptif:

1. Untuk mengukur pencapaian aspek kognitif, afektif, dan psikomotor.

$S P=\frac{\text { skor perolehan }}{\text { skor maksimum }} \times 100$ (Arikunto, 2005)

2. Untuk mengukur nilai proses.

$$
N P=\frac{\text { Kognitif }+ \text { Afektif }+ \text { Psikomotor }}{3}
$$

3. Untuk memperoleh nilai akhir.

$$
N A=\frac{6 P+4 F}{10}
$$

4. Untuk mengukur kemampuan berpikir kritis siswa.

$$
\mathrm{S} 1=\frac{R 1}{N 1} \times 100(\text { Fisher, 2011) }
$$

Keterangan:

$\mathrm{S} 1$ = Nilai yang dicari

$\mathrm{R} 1$ = Jumlah skor yang diperoleh

$\mathrm{N} 1$ = Jumlah skor maksimum

\section{HASIL DAN PEMBAHASAN \\ Tes Awal (Pre-test)}

Hasil penelitian menggambarkan kemampuan awal siswa pada materi sel sebelum mengikuti kegiatan belajar mengajar dengan penerapan metode Inquiry dipadu trik taktik waktu bertanya, terlihat pada tabel 1.

Tabel 1. Kualifikasi Hasil Tes Awal

\begin{tabular}{cccc}
\hline Tingkat Pencapaian & Frekuensi (f) & Persentase (\%) & Kualifikasi \\
\hline $87-100$ & - & - & Sangat baik \\
\hline $81-86$ & - & - & Baik \\
\hline $75-80$ & - & - & Cukup \\
\hline $60-74$ & 2 & 10 & Kurang \\
\hline$\leq 55$ & 18 & 90 & Gagal \\
\hline Jumlah & 20 & 100 & \\
\hline
\end{tabular}

Tes awal (post test) adalah tes yang digunakan untuk mengukur seberapa jauh siswa telah memiliki kamampuan mengenai materi yang akan dipelajari (Sanjaya, 2008). Kemampuan awal siswa sebelum proses belajar mengajar dengan penerapan metode Inquiry dipadu trik taktik waktu bertanya, tergolong dalam kategori sangat rendah. Hal ini terlihat dari hasil tes awal (pre test) 2 siswa dengan persentase 10\% berada pada kualifikasi kurang, dan 18 siswa dengan persentase $90 \%$ berada pada kualifikasi gagal.
Hasil rata-rata tes awal yang dicapai siswa tidak memenuhi KKM yaitu sebesar 31 dari yang ditetapkan yaitu 75 . Hal ini disebabkan karena sebelum guru memberikan materi, siswa belum ada respon dan masih pasif sehingga belum ada hasil yang baik dan setiap siswa memiliki kemampuan berpikir yang berbeda-beda. 


\begin{abstract}
Penilaian Selama Proses Belajar Mengajar

Proses belajar mengajar secara umum dapat diartikan sebagai sebuah aspek perubahan tingkah laku yang terjadi pada diri siswa. Menurut Bloom (2008) dalam Sanjaya (2008) ada tiga aspek dalam menilai hasil belajar antara lain: aspek kognitif, afektif, dan psikomotor.
\end{abstract}

\section{Hasil Penilaian Aspek Kognitif}

Hasil penilaian kemampuan kognitif siswa selama proses pembelajaran dalam hal ini siswa mengerjakan lembar kerja siswa (LKS) yang digunakan untuk melihat hasil kerja siswa di kelas dapat dilihat pada tabel 2.

Tabel 2. Kualifikasi Penilaian Rata-Rata Hasil Kognitif

\begin{tabular}{cccc}
\hline Tingkat Pencapaian & Frekuensi (f) & $\begin{array}{c}\text { Persentase } \\
(\%)\end{array}$ & Kualifikasi \\
\hline $87-100$ & 13 & 65 & Sangat baik \\
\hline $81-86$ & 7 & 35 & Baik \\
\hline $75-80$ & - & - & Cukup \\
\hline $60-74$ & - & - & Kurang \\
\hline$\leq 55$ & - & - & Gagal \\
\hline Jumlah & 20 & 100 & \\
\hline
\end{tabular}

Pada aspek kognitif (Penilaian pada LKS) diperoleh pencapaian yang tergolong dalam kualifikasi sangat baik dan baik. Hal ini dapat dibuktikan dengan 13 siswa dengan persentase $(65 \%)$ memperoleh nilai dengan interval (87-100) yang menunjukkan kualifikasi sangat baik dan 7 siswa dengan persentase (35\%) memperoleh nilai dengan interval (81-86) yang menunjukkan kualifikasi baik. Jika dibandingkan antara nilai KKM dengan dengan rata-rata skor pencapaian siswa pada aspek kognitif, maka dapat dikatakan pencapaian kognitif siswa berada pada kualifikasi tuntas dengan rata-rata skor pencapaian adalah $88,70 \%$.

Hal ini menggambarkan bahwa tingkat penguasaan konsep biologi pada siswa tentang sel yang sebelumya rendah telah diperbaiki pada saat proses belajar mengajar dengan perapan metode inquiry dipadu trik taktik waktu bertanya. Peningkatan penguasaan konsep siswa ini tampak dari LKS yang dikerjakan oleh siswa, siswa dapat membuat pertanyaan yang tepat dan logis berdasarkan gambar yang terdapat pada LKS serta menjawab pertanyaan tersebut dengan benar.

\section{Hasil Penilaian Aspek Afektif}

Data dari penilaian aspek afektif diperoleh melalui lembar observasi yang digunakan untuk menilai kemampuan siswa yang meliputi: peran aktif, menghargai pendapat teman, kerja sama dengan pasangan, memberi kesempatan kepada teman. Hasil dari aspek afektif dapat dilihat pada tabel 3.

Tabel 3. Kualifikasi Penilaian Rata-Rata Hasil Afektif

\begin{tabular}{cccc}
\hline Tingkat Pencapaian & Frekuensi (f) & Persentase (\%) & Kualifikasi \\
\hline $87-100$ & 19 & 95 & Sangat baik \\
\hline $81-86$ & 1 & 5 & Baik \\
\hline $75-80$ & - & - & Cukup \\
\hline $60-74$ & - & - & Kurang \\
\hline$\leq 55$ & - & - & Gagal \\
\hline Jumlah & 20 & 100 & \\
\hline
\end{tabular}

Pada aspek afektif tergolong dalam kualifikasi sangat baik dan baik. Hal ini dapat dibuktikam dengan 19 siswa dengan persentase $95 \%$ memperoleh nilai yang intervalnya (87-100) dengan kuaifikasi sangat baik, dan 1 siswa dengan 
persentase $5 \%$ memperoleh nilai yang intervalnya (81-86) dengan kualifikasi baik. Jika dibandingkan antara nilai KKM dengan rata-rata skor pencapaian siswa pada aspek afektif siswa berada pada kualifikasi tuntas dengan rata-rata skor pencapaian adalah $92,97 \%$.

Pencapaian kualifikasi ini membuktikan adanya peningkatan penguasaan konsep siswa. Peningkatan penguasaan konsep biologi siswa terlihat dalam proses pembelajaran dengan penerapan metode Inquiry dipadu trik taktik waktu bertanya, siswa mampu merespon dengan baik proses pembelajaran yang berlangsung. Hal ini ditunjukan dengan bagaimana siswa dapat berperan aktif dalam proses belajar mengajar, siswa dapat menghargai pendapat yang disampaikan oleh teman, siswa dapat bekerja sama dengan pasangannya, dan siswa dapat memberikan kesempatan kepada teman.

\section{Hasil Penilaian Aspek Psikomotor}

Berdasarkan data hasil penilaian aspek psikomotor dengan menggunakan penilaian proses belajar mengajar yang dinilai berdasarkan 4 indikator yaitu melakukan langkah-langkah pada LKS, ketelitian menentukan nama dari organel-organel sel, menyelesaikan LKS tepat waktu, dan menggali informasi yang ada. Hasil dari aspek afektif ini dapat dilihat pada tabel 4.

Tabel 4. Kualifikasi Penilaian Rata-Rata Hasil Psikomotor

\begin{tabular}{cccc}
\hline Tingkat Pencapaian & Frekuensi (f) & $\begin{array}{c}\text { Persentase } \\
(\%)\end{array}$ & Kualifikasi \\
\hline $87-100$ & 14 & 70 & Sangat baik \\
\hline $81-86$ & 6 & 30 & Baik \\
\hline $75-80$ & - & - & Cukup \\
\hline $60-74$ & - & - & Kurang \\
\hline$\leq 55$ & - & - & Gagal \\
\hline Jumlah & 20 & 100 & \\
\hline
\end{tabular}

Pada aspek psikomotor tergolong dalam kualifikasi sangat baik dan baik. Hal ini dapat dibuktikan dengan 14 siswa dengan persentase $70 \%$ memperoleh nilai dengan interval (87-100) dengan kualifikasi sangat baik, dan 6 siswa dengan persentase $30 \%$ memperoleh nilai dengan interval (81-86) dengan kualifikasi baik. Jika dibandingkan dengan nilai KKM dengan rata-rata skor pencapaian siswa pada aspek psikomotor, maka dapat dikatakan pencapaian psikomotor berada pada kualifikasi tuntas dengan rata-rata skor pencapaian adalah 90,32\%.Pencapaian pada aspek ini membuktikan adanya peningkatan penguasaan konsep siswa. Peningkatan penguasaan konsep biologi siswa terlihat dalam proses pembelajaran dengan menggunakan penerapan metode
Inquiry dipadu trik taktik waktu bertanya, ketika siswa mampu menentukan nama dari organel-organel sel, siswa dapat mendeskripsikan organel-organel sel, siswa dapat menyelesaikan LKS tepat waktu serta siswa dapat melakukan langkah-langkah pada LKS dengan baik. Rehena (2009), menyatakan bahwa penilaian hasil belajar yang sifatnya psikomotor dapat dilakukan secara langsung melalui observasi terhadap siswa yang memperlihatkan keterampilanketerampilan sebagai hasil proses belajar.

\section{Penilaian Kemampuan Berpikir Kritis}

Hasil penilaian kemampuan berpikir kritis Kemampuan berpikir kritis siswa selama proses pembelajaran yang dinilai menggunakan lembar kerja siswa (LKS) dapat dilihat pada tabel 5 . 
Tabel 5. Kualifikasi Kemampuan Berpikir Kritis Siswa Melalui LKS

\begin{tabular}{|c|c|c|c|c|c|}
\hline \multirow[b]{2}{*}{$\begin{array}{c}\text { Tingkat } \\
\text { Pencapaian }\end{array}$} & \multicolumn{2}{|c|}{ Pertemuan I } & \multicolumn{2}{|c|}{ Pertemuan II } & \multirow[b]{2}{*}{ Kualifikasi } \\
\hline & $\begin{array}{l}\text { Frekuensi } \\
\text { (f) }\end{array}$ & $\begin{array}{c}\text { Persentase } \\
(\%)\end{array}$ & $\begin{array}{l}\text { Frekuensi } \\
\text { (f) }\end{array}$ & $\begin{array}{c}\text { Persentase } \\
(\%)\end{array}$ & \\
\hline $87-100$ & 11 & 55 & 19 & 95 & Sangat Tinggi \\
\hline $81-86$ & 2 & 10 & 1 & 5 & Tinggi \\
\hline $75-80$ & 7 & 35 & - & - & Cukup \\
\hline $60-74$ & - & - & - & - & Rendah \\
\hline$\leq 55$ & - & - & - & - & Sangat Rendah \\
\hline$\Sigma$ & 20 & 100 & 20 & 100 & \\
\hline
\end{tabular}

Bedasarkan penelitian yang telah dilakukan, diperoleh data kemampuan berpikir kritis siswa. Data diperoleh melalui lembar kerja siswa (LKS). Hal ini terlihat bahwa hasil dari penyelesaian LKS pada pertemuan pertama memiliki persentase rata-ratanya $86 \%$ yang masih tergolong tinggi. Sedangkan kemampuan berpikir kritis siswa memngalami peningkatan pertemuan kedua dengan persentase rata- ratanya $90,80 \%$ Hasil penilaian kemampuan berpikir kritis siswa selama proses belajar mengajar dinilai menggunakan lembar observasi. Ada 5 aspek yang dinilai yaitu: Memberikan pertanyaan, menganalisis data/informasi, mendefinisikan istilah, menarik kesimpulan dan rasa ingin tahu. Hasilnya dapat dilihat pada tabel 6.

Tabel 6. Kualifikasi Kemampuan Berpikir Kritis Siswa Melalui Lembar Observasi

\begin{tabular}{cccc}
\hline Tingkat Pencapaian & Frekuensi (f) & Persentase (\%) & Kualifikasi \\
\hline $87-100$ & 2 & 10 & Sangat Tinggi \\
\hline $81-86$ & 13 & 65 & Tinggi \\
\hline $75-80$ & 5 & 25 & Cukup \\
\hline $60-74$ & - & - & Rendah \\
\hline$\leq 55$ & - & - & Sangat Rendah \\
\hline Jumlah & 20 & 100 & \\
\hline
\end{tabular}

Berdasarkan penelitian yang telah dilakukan, diperoleh data kemampuan berpikir kritis siswa. Data diperoleh melalui lembar observasi menunjukkan bahwa 2 siswa dengan presentase $10 \%$ memperoleh skor dengan interval (87-100) dengan kualifikasi sangat tinggi, 13 siswa dengan persentase $65 \%$ memperoleh skor dengan interval (81-86) dengan kualifikasi tinggi dan 5 siswa dengan persentase 25\% memperoleh skor dengan interval (75-80) dengan kualifikasi cukup. Hal ini membuktikan bahwa kemampuan berpikir kritis siswa di atas rata-rata.

Nasution, (1999), menyatakan bahwa faktor utama yang menyebabkan peningkatan kemampuan berpikir kritis siswa adalah penerapan metode Inqury. Metode Inquiry memerlukan keterampilan berpikir yang banyak ragamnya termasuk mengamati, melaporkan, mendeskripsikan, mengananlisis, mengklasifikasikan, menafsirkan, mengkritik, meramalkan, menarik kesimpulan dari informasi yang dikumpulkan dan diolah. Hendra (2013) menyatakan bahwa penggunaan strategi trik taktik waktu bertanya di dalam proses pembelajaran juga memunculkan dampak keaktifan pada siswa untuk mengeluarkan pendapat dan dituntut untuk berpikir kritis yang memungkinkan siswa untuk menemukan kebenaran di tengah banyaknya kejadian/informasi yang ada.

\section{Hasil Tes Formatif}

Kualifikasi persentasi pencapaian siswa pada tes formatif yang dilaksanakan setelah proses kegiatan belajar mengajar dengan penerapan metode Inquiry dipadu trik taktik waktu bertanya dapat dilihat pada tabel 7 . 
Biopendix, Volume 5. Nomor 1, Oktober 2018, hlm. 37-44

Tabel 7. Kualifikasi Hasil Tes Akhir

\begin{tabular}{cccc}
\hline Tingkat Pencapaian & Frekuensi (f) & Persentase (\%) & Kualifikasi \\
\hline $87-100$ & 9 & 45 & Sangat baik \\
\hline $81-86$ & 8 & 40 & Baik \\
\hline $75-80$ & 3 & 15 & Cukup \\
\hline $60-74$ & - & - & Kurang \\
\hline$\leq 55$ & - & - & Gagal \\
\hline Jumlah & 20 & 100 &
\end{tabular}

Menurut Akyuwen (2015) dalam Sernasak (2017), tes formatif adalah tes yang digunakan untuk mengukur seberapa jauh siswa telah menguasai kompetensi tertentu seperti yang dirumuskan dalam indikator hasil belajar.

Berdasarkan Tabel 4.7 terlihat bahwa sebanyak 9 siswa (45\%) mampu menguasai indikator pembelajaran dengan kualifikasi sangat baik, 8 siswa (40\%) dengan kualifikasi baik, dan 3 siswa (15\%) dengan kualifikasi cukup. Jika dibandingkan dengan nilai KKM dengan rata-rata skor pencapaian siswa pada tes formatif, maka dapat dikatakan pencapaian kemampuan siswa berada pada kategori tuntas dengan rata-rata skor pencapaian pada tes formatif adalah $71,51 \%$ dari KKM yang ditetapkan.Dapat disimpulkan bahwa, proses pembelajaran dengan penerapan metode Inquiry dipadu trik taktik waktu bertanya dapat meningkatkan hasil belajar siswa pada konsep sel.

\section{Nilai Akhir}

Nilai akhir merupakan hasil belajar siswa yang dapat diketahui dari presentase tingkat penguasaan siswa pada nilai proses dari aspek kognitif, afektif dan psikomotor dan presentase penguasaan siswa pada hasil tes formatif. Tingkat penguasaan setiap siswa berbeda-beda, ini dapat terlihat dari hasil nilai akhir. Data kualifikasi nilai akhir (NA) dapat dilihat pada tabel 8.

Tabel 8. Kualifikasi Nilai Akhir

\begin{tabular}{cccc}
\hline Tingkat Pencapaian & Frekuensi (f) & Persentase (\%) & Kualifikasi \\
\hline $87-100$ & 18 & 90 & Sangat baik \\
\hline $81-86$ & 2 & 10 & Baik \\
\hline $75-80$ & - & - & Cukup \\
\hline $60-74$ & - & - & Kurang \\
\hline$\leq 55$ & - & - & Gagal \\
\hline Jumlah & 20 & 100 & \\
\hline
\end{tabular}

Berdasarkan hasil dibuktikan nilai akhir yaitu 18 siswa dengan persentase 90\% memperoleh nilai dengan interval (87-100) dengan kualifikasi sangat baik, sedangkan 2 siswa dengan persentase 10\% memperoleh nilai dengan interval (81-86) dengan kualifikasi baik. Jika dibandingkan dengan nilai KKM dengan rata-rata skor pencapaian siswa pada nilai akhir, maka dapat dikatakan pencapaian kemampuan siswa berada pada kategori tuntas dengan rata-rata skor pencapaian adalah $89,06 \%$.

\section{KESIMPULAN}

Berdasarkan hasil dan pembahasan, maka dapat disimpulkan bahwa penerapan metode Inquiry dipadu trik taktik waktu bertanya dapat meningkatkan kemampuan berpikir kritis siswa dan pencapaian hasil belajar biologi konsep sel, hal ini terlihat dari:

1. Adanya peningkatan kemampuan berpikir kritis siswa setelah diajarkan dengan penerapan metode Inquiry dipadu trik taktik waktu bertanya. Hal ini dibutikan melalui rata-rata hasil kerja LKS pada pertemuan pertama adalah $86 \%$, dan pada pertemuan kedua meningkat menjadi $90,80 \%$. 
2. Kemampuan awal seluruh siswa sebelum proses belajar mengajar tidak mencapai KKM dengan rata-rata tes awal adalah $31 \%$, dan setelah proses pembelajaran dilakukan dengan penerapan metode Inquiry dipadu trik taktik waktu bertanya, hasil belajar siswa dapat mencapai KKM, hal ini dibuktikan pada tes kemampuan akhir dengan perolehan nilai rata-rata mencapai $71,51 \%$.

\section{DAFTAR PUSTAKA}

Amien, M. 1987. Mengajarkan IImu Pengetahuan Alam (IPA) dengan Menggunakan Metode "Discovery" dan "Inquiry". Jakarta: Depdikbud.

Arikunto, S, 2012. Prosedur Penelitian Suatu Pendekatan Praktik. Jakarta: PT. Rineka Cipta.

Fisher, A. 2011. Berpikir Kritis Sebuah Pengantar. Jakarta: Erlangga.

Hendra, Surya. 2013. Cara Belajar Orang Genius. Jakarta: Elex Media Komputindo.

Nasution, 1999. Proses Belajar Mengajar. Bandung: Tarsito

Nurlitasari, 2015. Pengaruh Penerapan Metode Inquiry Untuk Meningkatkan Kemampuan Berpikir dan Hasil Belajar
Siswa Kelas X-2 SMA LAB UM Malang. Jurnal Euclid, (Online), 3(1): 377-525 (http://www.um.co.id), diakses 7 Januari 2018

Rehena, J.F., Casmudi. 2009. Strategi Pembelajaran. Malang: Universitas Negeri Malang.

Roswita, I. 2013. Penerapan Strategi Waktu Bertanya Untuk Meningkatkan Hasil Belajar Pendidikan Kewarganegaraan pada Materi Menjaga Keutuhan Indonesia Siswa Kelas V SDN 001 Teratak Kecamatan Rumbio Jaya Kabupaten Kampar. Skripsi tidak diterbitkan. Pekanbaru: UIN SUSKA Riau.

Sanjaya. 2008. Dasar-dasar Proses Belajar Mengajar. Bandung: Sinar Algensindo.

Saptono, S. 2003. Strategi Belajar Mengajar. Semarang: UNNES.

Sernasak, 2017. Penerapan Model Pembelajaran Think Pair Share (TPS) Dipadukan Dengan Sepak Bola Verbal Dapat Meningkatkan Keaktifan Dan Hasil Belajar Siswa Konsep Sistem Pernapasan Kelas XI IPA SMA Negeri 4 Ambon. Ambon: UNPATTI.

Sofa. 2008. Pendekatan Discovery, Inquiry dan STS dalam Pembelajaran Fisika. 